\title{
The Politics of Conscience in Reformation England
}

\author{
MEG LOTA BROWN
}

A

response to uncertainty about the compass of law and reason, casuistry was an important factor in Reformation debate about authority and interpretation. Also called case divinity or practical theology, casuistry is a system of defining, interpreting, and applying law and ethics according to the circumstances of a specific case. Practical theologians consult conscience, Scriptural principles, and reason, in order to determine the relation of general laws to particular experience. When public code unduly restricts private conduct, case divinity provides a system of equitable sanctions that protects the integrity of the individual. ${ }^{1}$ Case divinity constitutes a significant body of Renaissance literature, and its appeal in seventeenth-century England was considerable. From 1560 to 1660 , over 600 collected cases of conscience were published in England and Europe. Douglas Patey observes that "every major divine of the period wrote or spoke on conscience," and he describes the controversy between Protestant and Catholic casuists as "one of the greatest paper wars of the age." 2 Attention to practical theology was more widespread during the seventeenth century than at any time before or since. Casuistical epistemology influenced a great deal of post-Reformation thought; indeed, one intellectual historian claims,

There was no aspect of action or belief which was not in one way or another affected by the crisis over probabilism. ... Copernicus, Galileo, Descartes, Pascal, and other founders of modern science and philosophy (not excluding Newton) cannot be fully understood except in the light of the controversies (philosophical, theological, juridical) among probabilists and anti-probabilists on the nature of knowledge, opinion, certitude, ignorance, hypothesis, etc. $^{3}$

Clearly, a full examination of the influence of casuistry is inappropriate to the scope of this study, but the following pages will suggest some of the 
reasons for the appeal of practical theology in seventeenth-century England, for the transformations of continental casuistry in Britain, as well as ways in which casuists responded to political and religious controversies of the period.

The publication history of William Perkins' works provides a measure of Protestant casuistry's popularity in England. The first to systematize a Reformed version of practical theology, Perkins (1558-1602) was the mainstay of English casuists. During the first half of the seventeenth century, as many as eleven editions of Perkins' collected works, both pirated and authorized, were printed. Further evidence of Perkins' reception can be deduced from the number of his works included in anthologies; one collection, A Garden of Spiritual Flowers, underwent nine printings from $1609-38 .{ }^{4}$ According to a modern editor of Perkins' casuistical treatises, the author was better known to his time than Hooker. His works were translated into six languages, and "in an age when the literature of piety was exceedingly popular, he was probably read more widely than any other preacher of his day." Later writers of cases-William Ames, Richard Baxter, and Jeremy Taylor, for exampleacknowledged their enormous debt to Perkins. But his influence was not limited to England; in inventories of colonial American libraries, "one of the commonest entries is the work of William Perkins. ... [His] works are found listed in Virginia inventories almost as frequently as in books of New England."6

Perkins' popularity is partly attributable to the accessibility and practicality of his material. Stressing the application of Scripture to quotidian activities, he wrote about marital problems, godly speech, family duties, etc. His treatise on how to die well not only discusses preparing one's soul for death, but also offers more immediately practical advice about selecting a physician. Above all, Perkins translated into simpler terms the technical language and subtleties that characterized Catholic cases. His work, like that of his successors, made a system of addressing moral uncertainty available to all.

Thus one reason for the appeal of Protestant casuistry in England was the wide audience at which it aimed. Unlike Catholic cases of conscience, which were written in Latin for the priest's use in confessional, Reformed casuistry was almost always in the vernacular, and was intended for every Christian. Just as Protestant clergy were not intercessors between the faithful and God, Protestant casuists did not interpose themselves between individuals and their consciences. Rather, endorsing Luther's declaration of "the priesthood of all believers," they insisted that the answers to dilemmas should be sought in Scripture before they are sought in institutions or other individuals. All Christians were encouraged to be their own casuists. Directly accountable to 
God for their conduct, laymen were more engaged in their own moral direction than ever before. The audience of Protestant casuistry, then, was all believers, and the subject was all their actions.

But if individuals were to determine their own cases of conscience, what function did the hundreds of published cases serve? And what was the role of moral theologians who preached unmediated consultation of Scripture? Protestant casuists perceived themselves as advisors rather than legislators. Cases served as paradigms of deliberation, procedural manuals that readers could consult while adjudicating their own decisions. Because the reader's circumstances often varied from those of published cases, moral theologians pointed out that their resolutions were only provisional. Protestant casuists wrote not as absolute judges, but as reasonable investigators into all sides of an ethical dilemma. Jeremy Taylor explains in Ductor Dubitantium: "Where I had not certainty in a case, or that the parts of a question were too violently contended for, with sufficient evidence on either side, I have not been very forward to give my final sentence, but my opinion and reason."7

Opinion and reason were the province of Reformed casuists. Their role consisted of quieting or aggravating conscience, of setting forth alternatives and consequences, of providing models for weighing moral responsibilities. The judgments of their Catholic counterparts, however, were less tentative. The Roman Church allowed its casuists complete jurisdiction over conscience. As early as the third century, the Didascalia proclaimed that priests "are in the place of God and have received power to bind and loose. This power applies to all sins." 8 The priest's jurisdiction combined with mandatory confession to strengthen the authoritarianism of Catholic casuistry. Reformers objected to such control over conscience; Perkins, for example, criticizes the Roman assumption that casuists

are made by Christ himselfe judges of the Cases of Conscience, having in their owne handes a judicarie power and authoritie, truely and properly to bind or loose, to remit or to retaine sinnes, to open or shut the kingdome of heaven. Whereas the Scripture uttereth a contrarie voyce, that Christ onely hath the keyes of David. ... And the ministers of God are not called to be absolute Judges of the Conscience, but onely Messengers and Embassadours of reconciliation. ${ }^{9}$

While the resolutions of Catholic cases were authoritative, English casuists maintained that individuals' final decisions must be their own. Protestant "Embassadours of reconciliation" insured the popularity of casuistry by including the laity in the diplomacy of conscience. 
Still another appeal of casuistry was its ability to address the political and religious perplexities that beset seventeenth-century England. In the battles among Catholics, Anglicans, Puritans, pope and monarch, foreign and domestic governments, each faction warned that obedience to the other could imperil one's soul-and in some cases, one's family, livelihood, and possessions. "Surplices became scruples and devotional practices doubts, so that not only in moral questions, but in allied matters of ecclesiastical authority and obedience, the necessity for clear expositions of conscience, its nature, its doubts and its perplexities was obvious." 10 Casuistry met a concrete need for guidance of the conscience; it enabled individuals to measure their options and to govern their actions when confronted with conflicting authorities of the period.

The Reformation engendered numerous cases of conscience. English Catholics during the Armada threat, for example, had to determine whether treason or disobedience of the Pope was a greater violation. On one hand, the Papal Bull "Regnans in Excelsis" had excommunicated Elizabeth, and had declared that those who defended her not only sinned, but were in jeopardy of excommunication themselves. On the other hand, allegiance to Rome meant supporting the invasion and overthrow of their country. The vast majority of English Catholics chose in favor of Elizabeth. Patrick McGrath suggests that their reasoning is represented in a casuistical tract which asks, "Whether catholics in England might take up arms to defend the queen and country against the Spaniards?" The author of the tract, a priest named Wright, argues that Philip's motive for attacking was political gain and not defense of the Faith. Since Christians owe political allegiance to the State and spiritual allegiance to the Church, and since Spain's chief objective was not religious, English Catholics were bound in conscience to resist a foreign aggressor. As if often true in practical theology, Wright gives decisive importance to the motive of an act, and he limits his judgment to the specific case. "He did not repudiate the papal deposing power, but he argued that in this particular case Catholics were not bound to obey the Pope" (my emphasis). ${ }^{11}$ Always rooted in the occasion, casuistry enabled a concrete resolution without forcing English Catholics to betray their faith or to renounce the Pope.

In a period when antagonistic factions required oaths of obedience, the extent of an individual's duty to civil and ecclesiastical authorities was a common subject of casuistry. Bishop Sanderson's "Case of the Engagement" tries to reconcile a Royalist's conscience with the 1649 oath of loyalty to Parliament, and John Donne's Pseudo-Martyr examines why English Catholics should take the Oath of Allegiance to their Anglican king. ${ }^{12}$ Both cases 
argue for avoiding confrontation with the ruling powers, while taking great care that the conscience remains inviolate. For some in seventeenth-century England, casuistry was a means of physical as well as spiritual preservation.

But practical theology also provided less scrupulous means of self-preservation. From 1580, when the first Jesuits arrived in England, equivocation and mental reservation became associated with Roman casuistry. Both practices were intended to deceive authorities, and both could be enlisted when swearing oaths. Under the aegis of mental reservation, one could swear to the truth of a statement while mentally denying it. The Jesuit Campion promised his captors that his name was Butler, and then silently added, "It is the name that I have assumed for the moment in order to avoid persecution."13 Similarly, equivocation allowed one to deceive an interlocutor by withholding information or misrepresenting facts. Robert Sanderson gives several examples of this practice in his De Juramenti Obligatione:

It is as if a Jesuit apprehended, should swear that he were a Smith, meaning that his Name was Smith; or an Apprentice commanded to tell where his Master is, should swear he died a month ago, meaning that he then died Stockings.... This Jesuitical doctrine licenseth the Lust of Lying and Perjury unto all impious Men. ${ }^{14}$

While mental reservation and equivocation may have popularized casuistry for those who were able to insure their safety without betraying their allegiance, most casuists condemned the two practices. Donne likens equivocation to "a Tower of Babel ... because therein no men can understand one another," and Juan Caramuel, a Catholic casuist, protests that "Mental reservations deprive human society of all security; they open the way to all lies and perjury; the wickedness of mendacity is not changed by calling it mental reservation, it is merely enveloping a poison with sugar and disguising vice as virtue." 15

Clearly, practical theology was vulnerable to abuse, and not all aspects of the doctrine met with approval. Indeed, by 1656 , when Pascal wrote his Provincial Letters, casuistry had acquired the notoriety that still attends it. ${ }^{16}$ But earlier in the century, case divinity was often a valued resource for the conscience torn between conflicting obligations. Protestant casuists, in particular, responded to the crisis of authority and interpretation that accompanied the Reformation. Their emphasis on practicality and accessibility, their role as advisors to conscience and reason, and their attention to the ethical problems that arose from contemporary debate insured them a wide audience in seventeenth-century England. 
One of the most publicized controversies between Catholic and Protestant casuists concerned the doctrine of probabilism. As noted earlier, the controversy exerted an enormous influence on post-Reformation philosophy. Probabilism states that if one has the support of authority, one may disregard a law, even though conceivably there are stronger arguments and more authorities in favor of the law. In its simplest form, the doctrine grants: "We may use a probable opinion even though the contrary be more probable"; however,

the more probable arguments which may be discounted are not the known but the unknown arguments for the law. Once you have a reasonable and weighty doubt, you need not become involved in the interminable discussions which would be necessary to weigh up the balance of probability on either side. ${ }^{17}$

Such, at least, was the original conception of the doctrine. But the practicality of probabilism quickly yielded to opportunism, and the theory became a notorious vehicle for moral sophistry.

Bartholomew Medina of Salamanca, a Catholic casuist, formulated probabilism in 1577 . His intention was to offer a solution for those who must decide a case of conscience without the time or resources to weigh all arguments for and against the decision. The doctrine was to aid the overly scrupulous who were unable to act because of fear that an unanticipated argument may prove the action sinful. To circumvent such paralysis, Medina asserts, "if an opinion is solidly probable, the bare possibility that it might in the end prove less probable than its opposite need not deter us from acting upon it." 18 The definition of a probable opinion was any view sanctioned by the Catholic Church-its popes, councils, traditions, theologians, casuists. The greater the number of authorities that endorsed the view, the more probable the view was. ${ }^{19}$ Francisco Suarez, also a Spanish casuist, stipulates that a probable opinion "must not run counter to any truth universally accepted by the Church; it must be in agreement with common sense ... and supported by good authority, and if it has not the support of the majority of authorities, it must at all events not be an opinion generally abandoned." 20 From its inception, probabilism was an authoritarian doctrine.

Despite limitations imposed on probabilism, the theory was vulnerable to exploitation. Gabriel Vazquez, a Jesuit casuist, attempted to forestall misapplication of the doctrine when he declared that one may not invoke it at the expense of charity. And Medina warns: "For an opinion to be probable, it is not enough that specious reasons can be adduced on its side, nor that it should 
have champions and defenders - any error might be adjudged probable at that rate. It must be asserted by wise men and confirmed by the best arguments." 21 Nevertheless, probabilism became a means of escaping moral law and rationalizing misconduct. The most publicized abuses were those of Jesuits who taught that one may act upon any probable opinion, despite one's knowledge of more probable arguments to the contrary. Moreover, revising Medina's stipulations that several reputable authorities must support one's decision, Jesuits countenanced as probable the judgment of a single Church official, even if the respected majority disagreed. In allowing one to choose the least probable of a number of conflicting opinions, the doctrine enabled actions that received no support from conscience. Juan Azor's Institutionales morales (1600) states that one may act upon what an established authority has adduced to be lawful, even when one's own sense of rectitude is otherwise. In many cases, then, "we may follow a probable opinion against our best judgment. ... No longer bound to follow his own judgment, one no longer acts in his own right; in electing to follow a probable opinion, he assumes a role or mask to which his self is largely irrelevant."22

The irrelevance of conscience to probable judgments was precisely what Reformers objected to. By the time Protestants developed their own system of casuistry, Jesuitical probabilism had eclipsed Medina's original formulation. Not only did probabilism enable one corrupt authority to legitimate error, but it relieved the laity from the responsibility of adjudication. It enforced opinions in which the individual neither participated nor even necessarily believed. Reformers claimed that the self is disqualified from moral deliberation when external authority is the source of all decisions. Taylor summarizes the Protestant position on probabilism: "By this principle, you may embrace any opinion of their doctors safely ... and you need not trouble yourself with any further inquiry ... and Christ is not your rule-but the examples of them that live with you, or are in your eye and observation, that is your rule." 23 Probabilism constituted yet another skirmish in the battle between Reformed and Catholic casuists about proper criteria for judgment.

The Protestant alternative to probabilism was probabiliorism. As its name suggests, the Reformed doctrine required that one choose the more probable solution to a case of conscience-that is, the solution that best corresponds to one's understanding of Scripture. Ductor Dubitantium declares, "the greater probability destroys the less."(p. 111) The Protestant standards of reason, conscience, and Revelation determined whether one act was 'probabilior' than another. Emphasizing inquiry and deliberation, Ames writes: "everyone ought to follow the opinion which (after due diligence to 


\section{8 / Renaissance and Reformation}

search the truth) he judges to be more probable out of the nature of the thing and the law of God compared together." ${ }^{24}$ Reformed casuists further insisted that one's decision have the full persuasion of conscience. A convinced conscience need not believe that it has arrived at immutable truth, but it must be assured that of the options discernible to fallen reason, it has chosen the one that best conforms to Biblical principles. A convinced conscience intends virtue, even if it is in error. To the Catholic objection that inner persuasion is a subjective standard, Protestants replied that Scripture and conscience are God's instruments; together, they create a "divine spark" which it is sin to disregard.

Despite their different priorities in assessing moral choices, Reformed and Catholic casuists agreed that probability is a sufficient basis for judgment. They recognized that absolute truth may not be within the province of fallen reason, but they maintained that grace and Revelation enabled one to achieve practical assurance. Casuistry offered a method of weighing authorities, of evaluating laws and circumstances so as to guide the uncertain in righteousness, if not to guarantee deliverance from all error. Taylor remarks in Ductor Dubitantium, "This heap of probable inducements is not of power as a mathematical and physical demonstration, which is in discourse as the sun is in heaven, but it makes a milky and a white path, visible enough to walk securely."(pp.36-7) The epistemological concessions of casuists, their constructive response to doubt, their concern with enabling action, and their belief in the importance of reason to faith and virtue earned them a prominent position among practical philosophers of sixteenth- and seventeenth-century Europe.

Perhaps the most important contribution of casuistry to post-Reformation thought was its response to the "rule of faith" controversy-a debate between Protestants and Catholics which challenged received notions of authority and raised far-reaching questions about criteria for judgment. Central to the development of Reformed casuistry, the rule of faith crisis posed an epistemological problem: how can we justify the foundation of our knowledge? Both Protestants and Catholics agreed that Scripture is truth; their argument was how to determine whether one had correctly interpreted that truth. Catholics insisted that Scripture is obscure, and that reason alone is unable to fathom God's Word. Consequently, as Erasmus maintains in De Libero Arbitrio, man's fallen judgment needs the guidance of the Church, whose authority for interpretation derives from Scripture and tradition. ${ }^{25}$ Protestants agreed that reason is fallible. Indeed, they argued that very fact to undermine the reliability of Popes and council, whose interpretation of Scripture was 
mere opinion derived from corrupted reason. Reformers added that tradition, far from authoritative, consisted of more than a thousand years of controversy about even the most essential articles of faith. Truth, they argued, is perfect and unified; the Catholic tradition was neither. Concerning the Roman Church's claim that its interpretation of God's Word had Biblical authorization, Protestants pointed out that the controversy itself was about exegesis, and that therefore an objective criterion outside the debate was necessary. This criterion, they argued, was conscience, combined with faith. God places in us an undeniable conviction which authorizes the judgments of conscience.

The Catholics countered on their antagonists' own grounds: since all individuals are corrupted, individual conscience and reason are unable to dispense absolute truth. Erasmus (and later counter-Reformers, Pierre Charron, Gentian Hervet, François Veron) contended that while Church authorities are subject to error, the consensus of all the orthodox faithful, the saints, scholars, martyrs, Church Fathers, bishops, popes, and councils outweighed the self-professed authority of Luther or any other individual. ${ }^{26}$ Catholics further objected that the standards of conscience and inner persuasion fostered religious anarchy; there were as many different interpretations of Scripture as there were Christians. Only the established Church could rightfully teach the ways to salvation. ${ }^{27}$

While legitimate criteria for judgment continued to be a source of debate, the fallibility of canon law, Church officials, and tradition was not the primary objection of Reformed casuists to Catholic standards. Indeed, Protestants weighed all three factors in their deliberation of cases, just as Catholic casuists referred to Scripture and right reason in theirs. The chief contention between the two systems was how to apply their standards; at issue were emphasis and accountability. In Reformed casuistry, individuals were accountable for their own moral deliberation and for the reasons that fortified their decision. They, and not Church appointed authorities, were the final arbiters of their cases. Jeremy Taylor's Dissuasive From Popery reminds its audience, "We are commanded to 'ask in faith', which is seated in the understanding, and requires the concurrence of the will." 28 Faith, understanding, and will: none of these are exercised when theologians make our decisions for us. Those who govern conduct solely by the dictates of tradition, Church officials, or canon law do not necessarily comprehend the moral principles on which they act. Not only must ratiocinative effort precede action, but to commit an act without the persuasion of reason is to $\sin .{ }^{29}$ According to Protestants, Roman authoritarianism excluded the laity from the process of reasoning; those in doubt consigned judgment to their priest, and thus abjured their Christian duty to 


\section{0 / Renaissance and Reformation}

participate in their own salvation. Reformed casuists objected that the Catholic policy left the faithful more dependent on human intercession than on God's Word in conscience. As William Ames remonstrates, conscience "is immediately subject to God, and his will, and therefore it cannot submit it selfe unto any creature without idolatry." 30

The rule of faith controversy established the positions that Protestant and Catholic casuists would later take in adjudicating cases of conscience. At the outset of controversy, however, Protestant casuistry did not exist, and the debate evinced the Reformer's need to develop a system that governed actions according to the criteria they supported. In addition to charges of ethical relativism, Protestants faced the problem of guiding conscience without the sacrament of penance, the confessional, or the Catholic system of casuistry. ${ }^{31}$ The latter, with its dependence on Church authorities as the final arbiters of truth, was inimical to Reformed standards of evaluating judgment. Luther's burning Angelo de Clavasio's Summa concerning the Cases of Conscience dramatized the Reformed attitude toward existing practical theology. Thomas Merrill observes:

What was needed, and needed desperately, was a system of morality to complement Reformation dogma. The formulation of such a system would have enormous influence in shaping the character of English social and political attitudes, for it would be in fact nothing less than the practical instrumentation of the revolutionary changes that had already been brought about in theory. ${ }^{32}$

During the first half of the seventeenth century, Protestants responded to the need that Merrill describes by formulating a Reformed version of case divinity. Defining itself against the Catholic system of applied morality, Reformed casuistry implements the ideology set forth in the rule of faith controversy. In the process, practical theologians provided a method of evaluating the political and philosophical conflicts that beset the period. As the most prominent figures of power-King, Pope, and later in the century, Parliament-jockeyed for greater jurisdiction, each called into question the very basis of the other's authority. Ironically, the more absolute their conflicting claims of authority became, the more they forced the individual to judge for himself the limits of their jurisdiction over his own experience. The perplexity of allegiance, combined with Protestant emphasis on self-reflective determination of moral dilemmas, led seventeenth-century Reformers to assume increasing authority for their own actions-led them, in other words, to become their own casuists. While both James and the Pope claimed to be 
the highest authority on earth, Reformed casuists taught that no authority was greater than the individual's understanding of Scripture. During the early 1600 's, practical theology was the resource of moderates and conservative, but its elevation of conclusions drawn in conscience over institutionally mediated truths was potentially subversive. The role of casuistical principles in the breakdown of traditional institutions of authority later in the century is a promising subject for further study.

\section{University of Arizona}

\section{Notes}

1. Casuists presuppose the inability of reason and language to formulate precepts comprehensive enough to solve all moral dilemmas. Consequently, they recognize that the literal application of law is not always just. In his description of equity, Aristotle outlines the foundation of case divinity; Aquinas, an authority for both Protestant and Catholic casuists, reproduces the following passages from Nichomachean Ethics in his Summa Theologica:

Every law is expressed in general terms, and there are some matters that cannot be dealt with in general terms. ... In such cases the law lays down what is right for the majority of cases, without losing sight on the consequent inaccuracy [in the remainder]. ... When, therefore, a law is laid down generally, but manifest ground for exception appears in a particular case, it is right that this failure of the legislator (due to his expressing himself in general terms) should be made good exactly as he would make it good if he were present, or would amend his law if he took the case into account.

Nichomachean Ethics, 1137b in The Basics Works of Aristotle, ed. Richard McKeon (New York: Random House, 1941). See Aquinas, Summa Theologica, ed. Anton Pegis (New York: Random House, 1948), 11.2. 120. See also Joseph Hall, Resolutions and Decisions of Divers Practical Cases of Conscience, Vol. XII of Works ed. John Downame (Oxford: D. C. Talboys, 1937), p. 311.

2. Douglas Lane Patey, Probability and Literary Form (Cambridge: Cambridge University Press, 1984), p. 56.

3. Benjamin Nelson, "Response to Edward Grant," Daedalus, 91 (1962), p. 614. Casuistry was not new to the Reformation. Nelson remarks that from 1215, when the Fourth Lateran Council required Catholics to attend confessional at least once a year, collections of cases provided valuable instruction and precedents for priests. However, confession and penance were practiced well before the Lateran decree, and in confessors' manuals dating from the sixth century one can discover the prototype of Catholic casuistry.

4. Louis B. Wright, "William Perkins: Elizabethan Apostle of 'Practical Divinity," Huntington Library Quarterly, 3, No. 2 (1940), p. 193.

5. Wright, p. 196.

6. Wright, pp. 194-5. 
7. Jeremy Taylor, Ductor Dubitantium, Vol. 3 of The Whole Works, 3 vols. (London: Henry Bohn, 1844), p. 52.

8. John T. McNeill, and Helena M. Gamer, eds. and trans., Medieval Handbooks of Penance (New York: Columbia University Press, 1938), p. 16.

9. William Perkins, The Whole Treatise of Cases of Conscience, ed. Thomas Merrill (Nieuwkoop: De Graaf, 1966), p. 83.

10. H. R. McAdoo, The Structure of Caroline Moral Theology (London: Longmans, Green and Co., 1949), p. 65.

11. Patrick McGrath, Papists and Puritans Under Elizabeth I (London: Blandford Press, 1967), p. 277.

12. For a fine discussion of Sanderson's case, see Camille Wells Slights, The Casuistical Tradition in Shakespeare, Donne, Herbert and Milton (Princeton: Princeton University Press, 1981), pp. 43-59.

13. Quoted in Thomas Wood, English Casuistical Divinity During the Seventeenth Century (London: Billing and Sons, 1952), p. 49.

14. Robert Sanderson, De Juramenti Obligatione in Works (Oxford: Oxford University Press, 1854), p. 202.

15. John Donne, Pseudo-Martyr (London: W. Stansby, 1610), p. 48; and Wood, p. 108.

16. Although Pascal's criticism of Jesuitical casuistry is partisan, there is sufficient evidence from the Catholics themselves that some Jesuits exploited case divinity. Popes Alexander VII and Innocent XI officially condemned a number of abuses, among them: "A son who has killed his father in a drunken brawl may rejoice at the fact without sin if he has come into a large inheritance thereby"; and "calumniators, witnesses and unjust judges may be murdered if there is no other way of avoiding their attacks." Quoted in Kenneth E. Kirk, Conscience and Its Problems: An Introduction to Casuistry (London: Longmans, Green and Co., 1927), p. 118.

17. Kirk, Conscience and Its Problems, p. 391 and p. 393.

18. Kirk, p. 392.

19. In his Responsa Moralia (1609), the Catholic casuist Comitolus states that when reputable authorities "are found on both sides, the opinion which the greater number of them support must be chosen." Quoted in Kirk, p. 392.

20. Quoted in Kenneth Kirk, Some Principles of moral Theology and Their Application, (London: Longmans, Green and Co., 1926), p. 196.

21. Quoted in Kirk, Conscience and Its Problems, p. 392. Medina's restriction were often unheeded. Taylor's Dissuasive From Popery, Vol. 2 in Works pp. 797-8, lists a number of Catholic casuists who used probabilism to legitimate sin. Among them,

Martinus de Magistris says, To believe simple fornication to be no deadly sin, is not heretical, because the testimonies of Scripture are not express. ... Thus the most desperate things that ever were said by any ... are doctrines publicly allowed; they can also become rules of practice, and securities to the conscience of their disciples.

Abuse of probabilism became so widespread that Popes Alexander VII, Innocent XI, and Alexander VIII imposed increasingly severe restrictions on the doctrine. 
22. A.E. Malloch, "John Donne and the Casuists," Studies in English Literature, II, No. 1 (1962), p. 67.

23. Taylor, Dissuasive, p. 798.

24. Ames, Conscience With the Power and Cases Thereof in Works (Ann Arbor: University Microfilms, 1962), Bk. 1, p.86. Protestants did not discourage consulting wise authorities about perplexed or doubtful actions. But they did insists that the final weighing and choosing was the individual's own. In Ductor Dubitantium (p. 148), Taylor finds greater moral value in the search for truth than in its discovery. Indeed, Taylor acknowledges that truth can elude fallen man; therefore, "it is not necessary that truth should be found, but it is highly necessary it should be searched for. It may be, it cannot be hit, but it must be aimed at." Even if one is in error, "diligence to inquire, and honesty in consenting" determine the virtue of one's judgment.

25. Desiderius Erasmus, "The Freedom of the Will," in Erasmus/Luther: Discourse on Free Will, trans. and ed. Ernst F. Winter (New York: Frederick Ungar, 1961), pp. 12-20. For a more detailed discussion of the rule of faith debate and its epistemological ramifications, see Chapter One of Richard Popkin's History of Scepticism From Erasmus to Spinoza (Berkeley: University of California Press, 1979). See also Chapter Two of Henry Van Leeuwen's The Problem of Certainty in English Thought 1630-1690 (The Hague: Martinus Nijhoff, 1963), and Chapter Three of Barbara Shapiro's Probability and Certainty in Seventeenth-Century England (Princeton: University Press, 1983).

26. "The Freedom of the Will," pp. 10-20.

27. Inner persuasion was indeed a knotty standard. Popkin describes the circular reasoning that supports it: "the criterion of religious knowledge is inner persuasion, the guarantee of the authenticity of inner persuasion is that it is caused by God, and this we are assured of by our inner persuasion" p. 10. The 1554 execution of Miguel Servetus dramatized Catholic claims about the subjectivity of the standard (see Popkin, pp. 8-14). Inner persuasion led Servetus to preach against the doctrine of the Trinity. The same criterion convinced Calvin that anti-Trinitarianism is heresy, so he had Servetus burned at the stake. Sebastien Castellio, a Swiss Protestant attacked Calvin in De Haereticis, arguing that since fallen reason dims the truth, one is unjustified in killing another for 'misinterpretation.' Ages of debate, he asserted, prove that Scripture is obscure. In a diatribe against Castellio's "scepticism," Calvin and Beza responded that religious debate is not evidence of our inability to know truth; rather, it simply shows that some interpretations are wrong. While Reformed casuists supported inner persuasion, they objected to the dogmatism of Calvin's position.

28. Jeremy Taylor, Dissuasive From Popery, p. 799.

29. William Perkins, A Discourse of Conscience, ed. Thomas Merrill (Nieuwkoop: De Graaf, 1966), p. 41, asserts: "Whatsoever is not of faith, that is, whatsoever is not done out of setled perswasion in judgment and conscience out of God's word, howsoever men judge of it, is sinne. ... Therefore unlesse the conscience well informed first of all approove the thing to be good and agreeable to Gods will, it can be nothing els but a sinne."

30. William Ames, Conscience With the Power, Bk. 1, p. 6. 


\section{4 / Renaissance and Reformation}

31. Slights, p. 4. In Ductor Dubitantium (p. 47), Taylor concedes that Reformed casuists borrowed principles of law and interpretation from Catholic cases of conscience, but he adds: "We cannot be well supplied out of the Roman storehouses; for though there the staple is, and very many excellent things exposed to view; yet we have found the merchants to be deceivers, and the wares too often falsified." The authority upon which Catholic casuists base their judgments is the source of their "falsified wares":

the casuists of the Roman church take these things for resolution and answer to questions of conscience, which are spoken by an authority that is not sufficient; and they ... have not any sufficient means to ascertain themselves what is binding in very many cases argued in their canons, and decretal epistles, and bulls of Popes. ... Therefore either they must change their principle, and rely only upon Scriptures and right reason and universal testimonies, or give no answer to the conscience in very many cases of the greatest concernment; for by all other measures their questions are indeterminable. But the authority of man they make to be their foundation: and yet ... the doctors, whose affirmative is the decision of the case, are so infinitely divided. (p. 48).

32. Thomas Merrill, ed., Perkins' Discourse and Whole Treatise, p. xii. 